\title{
A novel frequent $B R C A 1$ recurrent variant c.5117G > A (p.Gly1206Glu) identified after 20 years of $B R C A 1 / 2$ research in the Baltic region: cohort study and literature review
}

P. Loza ${ }^{1,2^{*}}$ (D, A. Irmejs ${ }^{1}$, Z. Daneberga ${ }^{1}$, E. Miklasevics ${ }^{1}$, E. Berga-Svitina' ${ }^{1}$ S. Subatniece ${ }^{1}$, J. Maksimenko',

G. Trofimovics ${ }^{3}$, E. Tauvena ${ }^{3}$, S. Ukleikins ${ }^{3}$ and J. Gardovskis ${ }^{3}$

\begin{abstract}
Background: Several recent studies in the Baltic region have found extended spectrum of pathogenic variants (PV) of the BRCA1/2 genes. The aim of current study is to analyze the spectrum of the BRCA1/2 PV in population of Latvia and to compare common PV between populations of the Baltic region.

Methods: We present a cohort of 9543 unrelated individuals including ones with cancer and unaffected individuals from population of Latvia, who were tested for three most common BRCA1 founder PV. In second line testing, 164 founder negative high-risk individuals were tested for PV of the BRCA1/2 using next generation sequencing (NGS). Local spectrum of the BRCA1/2 PV was compared with the Baltic region by performing a literature review.

Results: Founder PV c.5266dupC, c.4035delA or c.181 T > G was detected in 369/9543 (3.9\%) cases. Other BRCA1/2 PV were found in 44/164 (26.8\%) of NGS cases. Four recurrent BRCA1 variants c.5117G > A (p.Gly1706Glu), c.4675G > A (p.Glu1559Lys), c.5503C > T (p.Arg1835*) and c.1961delA (p.Lys654fs) were detected in 18/44 (41.0\%), 5/44 (11.4\%), 2/44 (4.5\%) and 2/44 (4.5\%) cases respectively. Additionally, 11 BRCA1 PV and six BRCA2 PV were each found in single family.

Conclusions: By combining three studies by our group of the same cohort in Latvia, frequency of the BRCA1/2 PV for unselected breast and ovarian cancer cases is 241/5060 (4.8\%) and 162/1067 (15.2\%) respectively. The frequency of three "historical" founder PV is up to 87.0\% (369/424). Other non-founder PV contribute to at least 13.0\% (55/424) and this proportion probably will rise by increasing numbers of the BRCA1/2 sequencing. In relative numbers, c. $5117 \mathrm{G}>\mathrm{A}$ is currently the third most frequent PV of the BRCA1 in population of Latvia, overcoming previously known third most common founder variant c.181 T $>\mathrm{G}$. In addition to three BRCA1 founder PV, a total of five recurrent $B R C A 1$ and two recurrent BRCA2 PV have been reported in population of Latvia so far. Many of the BRCA1/ 2 PV reported in Latvia are shared among other populations of the Baltic region.
\end{abstract}

Keywords: BRCA1, BRCA2, C.5266dupC, C.4035delA, C.181 T> G, C.5117G > A (p.Gly1706Glu), C.4675G > A (p.Glu1559Lys), C.1961delA (p.Lys654fs), C.5503C > T (p.Arg1835*)

\footnotetext{
* Correspondence: peteris.loza@stradini.lv

${ }^{1}$ Riga Stradins University, Institute of Oncology, Riga, Latvia

${ }^{2}$ Pauls Stradins Clinical University Hospital, Riga, Latvia

Full list of author information is available at the end of the article
}

(c) The Author(s). 2021 Open Access This article is licensed under a Creative Commons Attribution 4.0 International License, which permits use, sharing, adaptation, distribution and reproduction in any medium or format, as long as you give appropriate credit to the original author(s) and the source, provide a link to the Creative Commons licence, and indicate if changes were made. The images or other third party material in this article are included in the article's Creative Commons licence, unless indicated otherwise in a credit line to the material. If material is not included in the article's Creative Commons licence and your intended use is not permitted by statutory regulation or exceeds the permitted use, you will need to obtain permission directly from the copyright holder. To view a copy of this licence, visit http://creativecommons.org/licenses/by/4.0/ The Creative Commons Public Domain Dedication waiver (http://creativecommons.org/publicdomain/zero/1.0/) applies to the data made available in this article, unless otherwise stated in a credit line to the data. 


\section{Introduction}

Pathogenic variants of the $B R C A 1$ and $B R C A 2$ genes $(B R C A 1 / 2)$ are established as most significant genetic risk factors for developing breast and ovarian cancers. Detection of germline pathogenic variants (PV) in asymptomatic carriers allows appropriate preventive actions including imaging and risk reductive surgical procedures to be taken, which can improve early detection and prevent the development of the disease. Moreover, in individuals with breast and/or ovarian cancer, the $B R C A 1 / 2$ status serves as an important guide for surgical treatment planning as well as medical management (chemotherapy and targeted therapy with poly (ADP-ribose) polymerase inhibitors (PARPi). The impact of discovered PV reaches far beyond individual level, often evoking cascade of genetic counselling and testing of many other family members. However, the initial high cost of sequencing of whole BRCA1/2 genes in some countries led to the concept of targeted founder PV testing that could detect majority of cases for a small fraction of cost.

The Polish publication about three BRCA1 founder variants (c.5266dupC, c.4035delA, c. $181 \mathrm{~T}>\mathrm{G}$ ) in year 2000 was supported by reports from other Baltic region countries which confirmed similar mutational spectrum [1]. The early studies between years $1999-2005$ by several groups in Latvia showed that two variants, c.5266dupC and c.4035delA constitute more than $80 \%$ of all PV identified by analysis of the entire $B R C A 1$ gene and they contribute to $3,7-5.7 \%$ and $9.9-17.3 \%$ of all consecutive breast and ovarian cancers respectively [26]. The third PV, c.181 T > G, was also confirmed in the population of Latvia, however, found much less frequently than in Poland, providing a concept for inexpensive founder PV testing in the country for all consecutive breast and ovarian cancers [7]. The concept was further supported by finding that $57.5 \%$ of $B R C A 1$ positive cases actually did not meet family cancer history criteria to qualify for $B R C A 1 / 2$ testing [7]. Similar results of all three common founder variants have been reported also from Lithuania and Belarus [8, 9]. However, in Estonia and west Russia only two founder PV (c.5266dupC and c.4035delA) have been reported [10, 11]. For more than a decade there was scarce published data about frequency of other PV of the BRCA1/2 in the Baltic region, which partially was related to relatively high cost of complete BRCA1/2 testing. Taking into account high frequency of two founder PV, someone could even speculate that the number of non-founder variants is negligible. This assumption was in concordance with several other studies mentioned below.

In our previous study in year 2013, non-founder PV of the $B R C A 1 / 2$ were identified in 4 out of 30 (13\%) founder-negative, high-risk breast/ovarian cancer families [7]. Around the same time, by screening 1068 breast cancer and 231ovarian cancer cases and performing complete $B R C A 1 / 2$ sequencing for a selected cohort of 160 cases, another group in Latvia concluded that the prevalence of non-founder $B R C A 1 / 2$ PV did not likely exceed $0.5 \%$ (CI 95\% 0.1-0.9\%) among unselected breast cancer cases and 1\% (CI 95\% 0-2.3\%) among unselected ovarian cancer cases [5].

Summary of $B R C A 1 / 2$ variant spectrum from Latvia, Lithuania, Poland and Russia was published in year 2018 in the worldwide review by Consortium of Investigators of Modifiers of BRCA1/2 (CIMBA), showing common founder variants in the Baltic region, however, containing relatively small number of reported non-founder variants [12]. The increasing availability of NGS technology lead to the most recent pilot study reported by our group, which found relatively high frequency of nonfounder $B R C A 1 / 2 \mathrm{PV}$, in seven out of sixteen (44\%) founder negative, high-risk breast/ovarian cancer families, including a novel recurrent pathogenic $B R C A 1$ variant c.5117G > A, which was found in two families in Latvia [13]. Findings of this pilot study mandated further research to reevaluate the true frequency and spectrum of non-founder PV of the BRCA1/2.

\section{Aim of the study}

To study the BRCA1/2 non-founder PV spectrum and frequency in Latvia and to compare it with published data from populations of the Baltic region.

\section{Materials and methods}

The retrospective data analysis of 9543 patients from the population of Latvia was performed. Individuals were tested for three BRCA1 founder PV (c.181 T > G; c.4035delA; c.5266dupC) from year 2004 to 2020 . In this cohort, 4927/9543 (51.6\%) had breast cancer, 1049/9543 (11.0\%) had ovarian cancer, 950/9543 (10.0\%) had other cancer and 2617/9543 (27.4\%) had no diagnosis of cancer at the time of testing.

Any one of following criteria were applied to select patients for the BRCA1 founder testing:

- Women with breast cancer and/or ovarian cancer regardless of age and family history

- Unaffected subjects who have first-degree or second-degree relatives with breast/ovarian cancers

In founder negative cases, any of following criteria was used to select high-risk individuals for further complete BRCA1/2 testing by NGS or Sanger sequencing:

- Manchester scoring system of 15 or more points [14] 
- Fulfil National Comprehensive Cancer network (NCCN) Hereditary Cancer Testing Criteria (version 1.2020,www.nccn.org)

Using above criteria and taking into account the availability of DNA samples, 164 individuals were selected for complete $B R C A 1 / 2$ testing by NGS. This testing was carried out either by means of a commercial service or as part of a research program at the Riga Stradins University, Institute of Oncology. This group consisted of 133/164 (81.1\%) cases of breast cancer, 18/164 (11.0\%) cases of ovarian cancer, $3 / 164(1.8 \%)$ cases of breast and ovarian cancers and 10/164 (6.1\%) unaffected high-risk individuals.

Commercial NGS for the clinical purpose was available since 2016. The patient samples were analyzed with different commercially available targeted panels for hereditary cancer in different commercial medical laboratories. For this research, we analyzed only the $B R C A 1$ and $B R C A 2$ gene sequencing results, obtained from commercial testing. Apart from commercial testing, 94/ 171 samples were analyzed in the RSU Institute of Oncology using AmpliSeq ${ }^{\text {tm }}$ BRCA Panel for Illumina ${ }^{\circ}$ (Illumina, USA) by iSeq100 system. The minimal coverage was $>100 x$.

All individuals provided written informed consent before genetic testing.

For literature review we searched Pubmed database to map the spectrum of published PV in countries of the Baltic region. We searched by entering "BRCA1 country, " and "BRCA2 country" and manually filtered out irrelevant studies. Only relevant studies containing data about pathogenic $B R C A 1 / 2$ variants from each country were selected. A total of 7/36, 7/39, 1/3, 22/386, 17/120 and 4/24 papers were selected from Latvia, Lithuania, Estonia, Poland, Russia and Belarus respectively. Recurrent PV were reviewed and summarized in the context of CIMBA worldwide review consisting of 29,700 families (Table 1) [12].

\section{Results}

Among 9543 unrelated individuals who underwent BRCA1 founder testing, a PV was found in 369/9543 (3.9\%) cases. Two variants, c.5266dupC and c.4035delA were detected in $211 / 369(57.2 \%)$ and $143 / 369$ (38.8\%) cases respectively. However, c. $181 \mathrm{~T}>\mathrm{G}$ was detected only in $15 / 369(4.0 \%)$ of cases. At the time of testing, in cohort of founder positive cases, 165/369 (44.7\%) had only breast cancer, 111/369 (30.0\%) had only ovarian cancer, 33/369 (8.9\%) had breast and ovarian cancers, $50 / 369$ (13.5\%) were unaffected individuals and 10/369 $(2.7 \%)$ were affected by other cancer (colorectal, prostate, urinary tract). Founder PV rate for unselected breast and ovarian cancer cases was 198/4927 (4\%) and 144/1049 (13.7\%) respectively.

A total of $164 / 9174$ (1.8\%) of founder negative highrisk individuals were selected and tested by NGS. A PV of the $B R C A 1 / 2$ was detected in 44/164 (26.8\%) of families, of which $38 / 44$ (86.4\%) were BRCA1 and 6/44 (13.6\%) were $B R C A 2$ positive. Four recurrent PV of the BRCA1, c.5117G > A, c.4675G > A, c.1961delA and c. $5503 \mathrm{C}>\mathrm{T}$ were detected in $18 / 44(40.1 \%), 5 / 44$ (11.4\%), 2/44 (4.5\%) and 2/44(4.5\%) of families respectively. All families with PV c.5117G > A were of Latvian ethnicity with no established relation. Additionally, 11 different PV of the BRCA1, c.1961dupA, c.2241delC, c.2481delA, c.3700_3704delGTAA, c.4065delTCAA, c.4689C > G, c.5095C > T, c.5256_5278-2757del, c.843_ 846delCTCA, rsa17q21.31(BRCA1 5'UTR-3'UTR) $\times 1$ (exon 1-23del) and c.-232-?_134+?del were each found in a single family.

There were no recurrent $\mathrm{PV}$ of the $B R C A 2$ detected in this study. Six PV of the BRCA2, c.1310_1313delAAGA, c.1813dupA, c.5946delT, c.8572C $>$ T, c.9381G $>$ A and c.9097delA were each found in single family (Table 2).

\section{Discussion}

Our data supports previously published data and confirms that c.5266dupC is the most common PV of the BRCA1 in population of Latvia, followed by second most common variant, c.4035delA $[3,5,6]$. A PV c. $181 \mathrm{~T}>\mathrm{G}$ was found only in minority, 15/369 (4\%) of all founder positive families, which is less than expected, because in previous publication by group from Latvia it was found in $6.4 \%$ of all founder positive cases [5].

Our study has the largest to date published cohort of non-founder BRCA1/2 PV families in Latvia. By sequencing 164 probands, we found a frequent recurrent BRCA1 missense PV c.5117G > A in 18/164 (11.0\%) of $B R C A 1 / 2$ tested families. This is a significant finding, indicating that this PV is very common in population of Latvia, moreover, all carriers of this PV being Latvians. We already have reported this PV in two families in our previous smaller cohort study, which sums up to 20 families in Latvia [13]. Probable explanation of late finding of this frequent PV is that this variant has been classified as pathogenic only since year 2015 , after being reviewed by the ENIGMA BRCA1/2 expert panel and submitted evidence to "ClinVar" database [25]. The loss of the BRCA1 function caused by this PV has also been confirmed by the "Database of Functional Classification of BRCA1 variants based on Saturation Genome Editing" [26]. However, this PV has initially been described in year 2003 (as BIC 5236G > A) in three Spanish families by the group in Spain [27]. The author estimated that this variant, together with the other three locally recurrent variants $(187-188 \mathrm{del} A \mathrm{G}, 330 \mathrm{~A}>\mathrm{G}, 5242 \mathrm{C}>\mathrm{A}$, and 
Table 1 Published number of families with recurrent BRCA1/2 pathogenic variants in different Baltic region countries and worldwide

\begin{tabular}{|c|c|c|c|c|c|c|c|}
\hline HGVS [15] & Latvia & Lithuania & Estonia & Russia & Poland & Belorussia & Worldwide (CIMBA [12]) \\
\hline \multicolumn{8}{|l|}{ BRCA1 NM_007294.3 } \\
\hline c. $181 \mathrm{~T}>\mathrm{G}$ & $\begin{array}{l}15 \text { (current study) } \\
7 \text { [5] }\end{array}$ & $\begin{array}{l}22[12] \\
15[8]\end{array}$ & - & $2[16]$ & $276[12]$ & $20[17]$ & Worldwide total 909 \\
\hline c.1961delA & $\begin{array}{l}2 \text { (current study) } \\
1[13]\end{array}$ & - & - & $\begin{array}{l}1[18] \\
1[12]\end{array}$ & - & - & $\begin{array}{l}\text { Worldwide total } 79 \\
\text { UK10 } \\
\text { Germany } 6\end{array}$ \\
\hline c. 2481 delA & 1 (current study) & $1[12]$ & - & - & - & - & - \\
\hline c.3700_3704delGTAAA & 1 (current study) & $2[12]$ & - & - & 10 [19] & - & $\begin{array}{l}\text { Worldwide total } 159 \\
\text { Germany } 57 \\
\text { Czech } 25\end{array}$ \\
\hline c.4035delA & $\begin{array}{l}147 \text { (current study) } \\
40[12] \\
43[2]\end{array}$ & $\begin{array}{l}113[12] \\
96[8]\end{array}$ & $\begin{array}{l}3[12] \\
6[20]\end{array}$ & $11[12]$ & 69 [12] & $17[17]$ & $\begin{array}{l}\text { Worldwide total } 304 \\
\text { Germany } 25\end{array}$ \\
\hline c. $4675 \mathrm{G}>\mathrm{A}$ & $\begin{array}{l}5 \text { (current study) } \\
1[5], 1[7]\end{array}$ & $1[12]$ & $1[20]$ & - & $1[21]$ & - & $\begin{array}{l}\text { Worldwide total } 5 \\
\text { Germany } 1 \\
\text { USA } 1\end{array}$ \\
\hline c. 4689 C $>$ G & 1 (current study) & $2[12]$ & - & $1[12]$ & $4[22]$ & - & $\begin{array}{l}\text { worldwide total } 104 \\
\text { Germany } 66\end{array}$ \\
\hline c. $5095 \mathrm{C}>\mathrm{T}$ & 1 (current study) & - & - & - & $1[22]$ & - & $\begin{array}{l}\text { Worldwide total } 37 \\
\text { Spain } 3 \\
\text { Germany } 13\end{array}$ \\
\hline c. $5117 \mathrm{G}>\mathrm{A}$ & $\begin{array}{l}18 \text { (current study) } \\
2 \text { [13] }\end{array}$ & $1[12]$ & $1[20]$ & $1[18]$ & - & - & $\begin{array}{l}\text { Worldwide total } 18 \\
\text { Spain } 13 \\
\text { UK } 1\end{array}$ \\
\hline c. $5251 C>T$ & - & - & - & - & $6[19]$ & - & $\begin{array}{l}\text { Worldwide total } 94 \\
\text { Germany } 9 \text { Austria } 16\end{array}$ \\
\hline c.5266dupc & $\begin{array}{l}211 \text { (current study) } \\
58[5]\end{array}$ & $\begin{array}{l}58[12] \\
56[8]\end{array}$ & $7[10]$ & $135[12]$ & $711[12]$ & $49[17]$ & Worldwide total 2942 \\
\hline c. $5346 \mathrm{G}>\mathrm{A}$ & - & - & - & - & $5[19]$ & - & $\begin{array}{l}\text { Worldwide total } 3 \\
\text { Germany } 2\end{array}$ \\
\hline c. $5503 C>T$ & 2 (current study) & $1[12]$ & - & $1[12]$ & - & - & $\begin{array}{l}\text { Worldwide total } 183 \\
\text { Germany } 53\end{array}$ \\
\hline c.68_69del & $\begin{array}{l}2([5]) \\
1[12]\end{array}$ & $\begin{array}{l}3[23] \\
3[12]\end{array}$ & - & $\begin{array}{l}7[12] \\
2[24]\end{array}$ & $\begin{array}{l}9[19] \\
2[12]\end{array}$ & - & $\begin{array}{l}\text { Worldwide total } 2301 \\
\text { Germany } 47\end{array}$ \\
\hline c.843_846delCTCA & $\begin{array}{l}1 \text { (current study) } \\
1[5]\end{array}$ & $\begin{array}{l}2[12] \\
1[23]\end{array}$ & - & - & - & - & $\begin{array}{l}\text { Worldwide total } 54 \\
\text { Germany } 13 \\
\text { Italy } 10\end{array}$ \\
\hline $\begin{array}{l}\text { c.-232-?_134+?del } \\
\text { exon 1-3del }\end{array}$ & 1 (current study) & $\begin{array}{l}3[8] \\
2[23]\end{array}$ & - & - & - & - & $\begin{array}{l}\text { Worldwide total } 11 \\
\text { Germany } 3 \\
\text { USA } 4\end{array}$ \\
\hline \multicolumn{8}{|l|}{ BRCA2 NM_000059.3 } \\
\hline c.3847_3848del & - & $4[12]$ & - & - & $1[12]$ & - & $\begin{array}{l}\text { Worldwide total } 169 \\
\text { Germany } 36\end{array}$ \\
\hline c.3974_3975insTGCT & - & - & - & - & $3[19]$ & - & - \\
\hline c.5946delT & 1 (current study) & - & - & $1([12])$ & $3[12]$ & - & $\begin{array}{l}\text { Worldwide total } 1401 \\
\text { USA } 723 \\
\text { Germany } 29\end{array}$ \\
\hline c.6267delG & - & - & - & - & 3 [19] & - & - \\
\hline c.646delG & $4[7]$ & - & - & - & - & - & - \\
\hline c.658delGT & $3[7]$ & - & - & - & - & - & - \\
\hline c.658_659del & - & $13[12]$ & - & - & $\begin{array}{l}1[12] \\
3[19]\end{array}$ & - & $\begin{array}{l}\text { Worldwide total } 130 \\
\text { Germany } 22\end{array}$ \\
\hline c.7913_7917delTTCCT & - & - & - & - & $3[19]$ & - & $\begin{array}{l}\text { Worldwide total } 37 \\
\text { Germany } 10\end{array}$ \\
\hline
\end{tabular}


Table 1 Published number of families with recurrent BRCA1/2 pathogenic variants in different Baltic region countries and worldwide (Continued)

\begin{tabular}{|c|c|c|c|c|c|c|c|}
\hline HGVS [15] & Latvia & Lithuania & Estonia & Russia & Poland & Belorussia & Worldwide (CIMBA [12]) \\
\hline & & & & & & & Denmark 7 \\
\hline c. $8572 \mathrm{C}>\mathrm{T}$ & 1 (current study) & $2[8]$ & - & - & - & - & $\begin{array}{l}\text { Worldwide total } 3 \\
\text { Italy } 2\end{array}$ \\
\hline c.9402delC & - & - & - & - & $5[19]$ & - & - \\
\hline c.9246_9247insA & - & - & - & - & $4[19]$ & - & - \\
\hline
\end{tabular}

589-590del) accounted for $46.6 \%$ of all BRCA1 detected PV in Spain. This data was further supported by large worldwide $B R C A 1 / 2$ report of 29,700 families by $C I M B A$ in year 2018, where this PV was reported in 13/189 (6.9\%) of Spanish BRCA1 positive families. However, in the same report, this particular variant was generally rare globally, reported only in $2 / 4317(0.05 \%)$ of $B R C A 1$ positive US families, and in a single family from UK, France and Lithuania [12]. This PV has also been reported in a single family in Russia and Estonia [18, 20]. More research with larger cohort is needed to assess the true frequency of this PV within the group of unselected breast/ovarian cancers. According to data from literature, Latvia and Spain have by far the largest number of families with this PV and haplotype studies between the populations should be considered to explain this unique finding.

The second significant finding from our study is a recurrent pathogenic missense variant c.4675G $>$ A (p.Glu1559Lys) that we detected in 5/164 (3.0\%)

Table 2 BRCA1/2 non-founder pathogenic variants

\begin{tabular}{|c|c|c|c|c|}
\hline HGVS [15] & Effect on protein & Mutation type & Mutation effect & No of Families \\
\hline Total & & & & 44 \\
\hline BRCA1 NM_007294.3 & & & & 38 \\
\hline c.1961delA & p.Lys654fs & FS & PTC & 2 \\
\hline c.1961dupA ${ }^{a, b}$ & p.Tyr655fs & FS & PTC & 1 \\
\hline c. 2241 delC $\mathrm{a}, \mathrm{b}$ & p.Asp749fs & FS & PTC & 1 \\
\hline c.2481 delA ${ }^{a}$ & Gly828fs & FS & PTC & 1 \\
\hline c.3700_3704delGTAAA a & p.Val1234fs & FS & PTC & 1 \\
\hline c.4065_4068delTCAA a,b & p.Asn1355fs & FS & PTC & 1 \\
\hline c. $4675 \mathrm{G}>\mathrm{A}$ & p.Glu1559Lys & MS & MS & 5 \\
\hline$c .4689 C>G^{a}$ & p.Tyr1563* & NS & PTC & 1 \\
\hline c. $5095 C>T^{a}$ & p.Arg1699Trp & MS & MS & 1 \\
\hline$c .5117 \mathrm{G}>\mathrm{A}$ & p.Gly1706Glu & MS & MS & 18 \\
\hline c.5256_5278-2757del a,b & - & LGR & PTC & 1 \\
\hline$c .5503 C>T^{a}$ & p.Arg1835* & NS & PTC & 2 \\
\hline c.843_846delCTCA & p.Ser282fs & FS & PTC & 1 \\
\hline rsa17q21.31 (BRCA1 5'UTR-3'UTR) $\times 1$, exon 1-23del ${ }^{a, b}$ & - & LGR & - & 1 \\
\hline $\begin{array}{l}\text { c.-232-?_134 +?del } \\
\text { exon 1-3del }{ }^{\text {a }}\end{array}$ & - & LGR & - & 1 \\
\hline BRCA2 NM_000059.3 & & & & 6 \\
\hline c.1310_1313delAAGA a,b & p.Lys437fs & FS & PTC & 1 \\
\hline c. 1813 dupA. ${ }^{a, b}$ & p.lle605Asnfs & FS & PTC & 1 \\
\hline c.5946delT ${ }^{a}$ & p.Ser1982fs & FS & PTC & 1 \\
\hline$c .8572 C>T^{a}$ & p.Gln $2858^{*}$ & NS & PTC & 1 \\
\hline c.9097delA ${ }^{a, b}$ & p.Thr3033Leufs & FS & PTC & 1 \\
\hline$c .9381 G>A^{a, b}$ & p.Trp3127* & NS & PTC & 1 \\
\hline
\end{tabular}

MS missense, NS nonsense, FS frameshift, LGR Large gene rearrangement, PTC premature truncating codon 
BRCA1/2 tested families. This PV has previously been reported in two other families in Latvia, one family in Lithuania and Estonia [5, 7, 8, 20]. In a recent report by $C I M B A$, this variant was reported in only five families Worldwide, one in each country - Germany, UK, USA, Latvia and Lithuania [12]. Moreover, in another study this PV was reported in three families in Germany and one family in Poland $[21,28]$. Currently Latvia has by far the highest reported absolute and relative numbers (seven unrelated families) of this PV in the world. However, there is little published data available about this $\mathrm{PV}$, and we propose that more research is needed to specify its frequency in the population of the Baltic region and the world more precisely.

Another recurrent BRCA1 pathogenic nonsense variant c. $5503 \mathrm{C}>\mathrm{T}$ was found in two families. It has previously been reported in 53 German, 20 British, one Lithuanian and one Russian family by CIMBA [12]. In publication by the Russian group, this PV was found in one subject after sequencing 95 high-risk founder negative breast cancer patients [18].

A pathogenic BRCA1 frameshift variant c.1961delA was detected in two families. This PV was already reported in our previous study in one Latvian family [13], so currently we propose this variant as recurrent in Latvia. Similarly, previously reported PV of the BRCA1 c.843_846delCTCA has been found in another family from our current study, also rendering this PV locally recurrent [5].

Eleven PV of the BRCA1 (c.1961dupA, c.2241delC, c.2481delA, c.3700_3704delGTAAA, c.4065_4068delTCAA, c. $4689 \mathrm{C}>\mathrm{G}, \quad$ c. $5095 \mathrm{C}>\mathrm{T}, \quad$ c. $5503 \mathrm{C}>\mathrm{T}, \quad$ c. 5256 5278-2757del, c.-232-?134+?del, rsa17q21.31 (BRCA1 5'UTR-3'UTR) $\times 1$ deletion encompassing whole BRCA1 gene) and all $6 \mathrm{PV}$ of the $B R C A 2$ from our current study are reported first time in Latvia (Table 2). However, eight of these variants have previously been reported in the Baltic region of which five have been reported in Lithuania (Table 1). Nine PV, including five of the BRCA1 and four of the BRCA2 have been reported in the Baltic region for the first time (Table 2).

For the $B R C A 1 / 2$ we have found 13 PV common between Latvia and Lithuania, 11 PV common between Latvia and Russia, 8 PV common between Latvia and Poland and $8 \mathrm{PV}$ common between Lithuania and Poland. We only found $4 \mathrm{PV}$ common between Latvia and Estonia, however, there is scarce published data available as we could find only one Estonian study and some data from $d b S N P$ database $[10,20]$. This underscores the close genetic, ethnic, historical and geographical relationships among the populations of the Baltic region. According to genetic constitution analysis of 3012 individuals from Europe by the group from Estonia, the genetic structures of populations of Latvia,
Estonia and Lithuania have major similarities and a significant overlap exists with populations of Poland and western Russia, forming a distinct Baltic region cluster [29]. It is also not surprising that several recurrent variants are shared with Germany, including three it's most frequent ones (c.5266dupC, c.181 T > G, c.4689C > G) as it has very long historical and geographical relationships with Baltic region too. At the same time someone could expect more common variants with another Baltic region country- Sweden, as only one Slavic founder mutation c.5266dupC is shared among the most frequent ones [12]. Over the last century, the ethnic structure of population of Latvia has changed significantly. Before the Second World War, in 1935, the proportions of Latvians, Russians, Jews, Germans, Poles, Belarussians, Lithuanians, Estonians were 76.9, 8.8, 4.9, 3.3, 2.6, 1.4 $1.2,0.4 \%$ respectively, and this proportion changed to $52.0,34.0,0.9,0.1,2.3,4.5,1.3,0.1 \%$ in 1989 and subsequently to $62.0,25.4,0.2,0.1,2.1,3.3,1.2,0.1 \%$ in 2017 [30]. As a result, a lot of current young generation Latvians have at least some genetic imprint from Russians, Jews, Germans and Poles.

One of the drawbacks of this study is still a relatively small number $(n=164)$ of founder negative high-risk families that we have sequenced.

\section{Conclusions}

In summary, by combining all three studies of the $B R C A 1 / 2$ reported by our group, which are covering the same cohort, the PV frequency for unselected breast and ovarian cancer cases is $241 / 5060$ (4.8\%) and 162/1067 (15.2\%) respectively. The prevalence of three "historical" founder PV in population of Latvia is up to 87.0\% (369/ $424)$ of all PV of the $B R C A 1 / 2$. Other PV contribute to at least $13.0 \%(55 / 424)$ of total $B R C A 1 / 2 \mathrm{PV}$, but the true spectrum and frequency of $B R C A 1 / 2 \mathrm{PV}$ still have to be defined more accurately by increasing the availability of complete $B R C A 1 / 2$ testing. However, already now we are able to confirm that at least one in 10 high-risk cases would be underdiagnosed if complete $B R C A 1 / 2$ testing is not routinely available.

We have identified five locally novel recurrent PV of the BRCA1 of which c.5117G > A and c.4675G > A are unexpectedly frequent. Findings of our study have very practical implications as addition of those 2 recurrent variants to the $B R C A 1 / 2$ screening test potentially will cover up to $94 \%$ of all presently known PV of the $B R C A 1 / 2$ in Latvia. These $2 \mathrm{PV}$ together with other recurrent PV of the BRCA1, three from current study (c.5503C > T, c.1961delA c.843_846delCTCA) and one previously reported recurrent PV, c.68_69del, along with two recurrent PV of the $B R C A 2$ from our previous study (c.646delG and c.658delGT) should be considered for inclusion in the local $B R C A 1 / 2$ founder screening kit. 
Additionally, 5 PV of the BRCA1 (c.2481delA, c.3700 3704delGTAAA, c. $4689 \mathrm{C}>\mathrm{G}, \quad$ c. $5095 \mathrm{C}>\mathrm{T}, \quad$ c. $-232-$ ?.134+?del) and 2 PV of the BRCA2 (c.5946delT, c. $8572 \mathrm{C}>\mathrm{T}$ ) that we found each in a single family in Latvia, have been reported in neighboring countries and hence could also be candidates for inclusion in local $B R C A 1 / 2$ screening kit.

Many common $B R C A 1 / 2$ pathogenic variants are shared between populations of the Baltic region, however still miniscule absolute numbers of tested families prevent the formation of complete picture. Interestingly, PV c.5117G > A and c.4675G > A have not been reported as recurrent in neighboring countries and there are only isolated cases reported from other populations of the Baltic region. Accordingly this finding underscores the possibility of finding new relatively frequent recurrent PV in populations, including neighboring ones, where limited number of cases have been tested for complete $B R C A 1 / 2$ so far.

According to the data of our study some corrections about five most frequent BRCA1 mutations in Latvia should be done to complement the earlier published data by CIMBA: Most frequent-c.5266dupC, second -c.4035delA, third- 5117G > A, fourth- c.181 T > G, fifthc. $4675 \mathrm{G}>\mathrm{A}$.

\section{Authors' contributions}

$\mathrm{PL}, \mathrm{Al}, \mathrm{ZD}$ and $\mathrm{EM}$ were major contributors in writing and reviewing the manuscript. EB contributed in processing of samples in the lab, SS, JM, PL, Al and GT contributed in selection of individuals for BRCA1 founder screening, ET and SU helped with selection of high risk individuals for BRCA1/2 sequencing. $\mathrm{PL}, \mathrm{JM}$ and $\mathrm{JG}$ contributed in the literature review. All authors read and approved the final manuscript.

\section{Funding}

This work was supported by Riga Stradins University grant "The Identification of Clinical, Pathologic and Genomic Factors for Escalation and De-escalation of Breast Cancer Treatment".

\section{Availability of data and materials}

The datasets generated and/or analyzed during the current study are available from the corresponding author on request.

\section{Ethics approval and consent to participate}

This study was approved by a Central Medical Ethics Committee of Latvia (03.6.2019. Nr.3/19-06-03) and Genome Research Council of Latvia (04.07.2019. Nr.A-12/19-07-04).

\section{Consent for publication}

All individuals provided written informed consent, including for publication.

\section{Competing interests}

All authors declare that they have no competing interests.

\section{Author details}

${ }_{1}^{1}$ Riga Stradins University, Institute of Oncology, Riga, Latvia. ${ }^{2}$ Pauls Stradins Clinical University Hospital, Riga, Latvia. ${ }^{3}$ Department of Surgery, Riga Stradins University, Riga, Latvia.
Received: 27 October 2020 Accepted: 5 January 2021

Published online: 19 January 2021

\section{References}

1. Gorski B, Byrski T, Huzarski T, Jakubowska A, Menkiszak J, Gronwald J, Płuzanska A, Bebenek M, Fischer-Maliszewska Ł, Grzybowska E, Narod SA. J. Lubin ski "founder mutations in the BRCA1 gene in polish families with breast-ovarian Cancer". Am J Hum Genet. 2000;66:1963-8. https://doi.org/10.1086/302922.

2. Tikhomirova L, Sinicka O, Smite D, Eglitis J, Hodgson SV. Aivars Stengrevics "high prevalence of two BRCA1 mutations, 4154delA and 5382insC, in Latvia". Familial Cancer. 2005;4:77-84.

3. Csokay B, Tihomirova L, Stengrevics A, Sinicka O, Olah E "Strong founder effects in BRCA1 mutation carrier breast cancer patients from Latvia," Mutation in brief no. 258, vol. 14, no. 92, 1999. DOl: 10.1002/(sici)10981004(1999)14:1<92::aid-humu23>3.0.co;2-2.

4. Gardovskis A, Irmejs A, Miklasevics E, Borosenko V, Bitina M, MelbardeGorkusa I, Vanags A, Kurzawski G, Suchy J, Górski B, Gardovskis J. Clinical, molecular and geographical features of hereditary breast/ovarian Cancer in Latvia. Hered Cancer Clin Pract. 2005;3(2):71-6.

5. Tihomirova L, Vaivade I, Fokina O, Peculis R, Mandrika I, Sinicka O, Stengrevics A, Krilova A, Keire G, Petrevics J, Eglitis J, Timofejevs M, Leja M. BRCA1 gene-related hereditary susceptibility to breast and ovarian cancer in Latvia. Adv Med Sci. 2014;59. https://doi.org/10.1016/j.advms.2013.09.002.

6. Plakhins G, Irmejs A, Gardovskis A, Subatniece S, Rozite S, Bitina M, Keire G, Purkalne G, Teibe U, Trofimovics G, Miklasevics E, Gardovskis J. Genotype- phenotype correlations among BRCA1 4153delA and 5382insC mutation carriers from Latvia. BMC Med Genet. 2011;12:147. https://doi.org/10.1186/1471-2350-12-147.

7. Berzina D, Nakazawa-Miklasevica M, Zestkova J, Aksenoka K, Irmejs A, Gardovskis A, Kalniete D, Gardovskis J, Miklasevics E. BRCA1/2 mutation screening in high-risk breast/ovarian cancer families and sporadic cancer patient surveilling for hidden high-risk families. BMC Med Genet. 2013; 14(61). https://doi.org/10.1186/1471-2350-14-61.

8. Janavicius R, Rudaitis V, Mickys U, Elsakov P, Griskevicius L. Comprehensive BRCA1 and BRCA2 mutational profile in Lithuania. Cancer Genet. 2014; 207(5):195-205. https://doi.org/10.1016/j.cancergen.2014.05.002.

9. Uglanitsa N, Oszurek O, Uglanitsa K, Savonievich E, Lubinski J, Cybulski C, Debniak T, Narod SA, Gronwald J. The contribution of founder mutations in BRCA1 to breast cancer in Belarus. Clin Genet. 2010;78:377-80. https://doi. org/10.1111/j.1399-0004.2010.01439.x.

10. Tamboom K, Kaasik K, Aršavskaja J, Tekkel M, Lilleorg A, Padrik P, Metspalu A, Veidebaum T. BRCA1 mutations in women with familial or early-onset breast cancer and BRCA2 mutations in familial cancer in Estonia. Hered Cancer Clin Pract. 2010;8. https://doi.org/10.1002/humu.9226.

11. Sokolenko AP, Rozanov ME, Mitiushkina NV, Sherina NY, lyevleva AG, Chekmariova EV, Buslov KG, Shilov ES, Togo AV, Bit-Sava EM, Voskresenskiy DA, Chagunava OL, Devilee P, Cornelisse C, Semiglazov VF, Imyanitov EN. Founder mutations in early-onset, familial and bilateral breast cancer patients from Russia. Familial Cancer. 2007. https://doi.org/10.1007/s10689-007-9120-5.

12. Rebbeck TR, et al. Mutational Spectrum in a worldwide study of 29,700 families with BRCA1 or BRCA2 mutations. Hum Mutat. 2018;39(5):593-620. https://doi.org/10.1002/humu.23406.

13. Maksimenko J, Irmejs A, Trofimovičs G, Bērziṇa D, Skuja E, Purkalne G, Miklaševičs $E$, Gardovskis J. High frequency of pathogenic non-founder germline mutations in BRCA1 and BRCA2 in families with breast and ovarian cancer in a founder population. Hered Cancer Clin Pract. 2018;16(12). https://doi.org/10.1186/s13053-018-0094-0.

14. Evans DG, Harkness EF, Plaskocinska I, Wallace AJ, Clancy T, Woodward ER, Howell TA, Tischkowitz M, Lalloo F. Pathology update to the Manchester Scoring System based on testing in over 4000 families. J Med Genet. 2017; 54(10):674-81. https://doi.org/10.1136/jmedgenet-2017-104584.

15. den Dunnen JT, Dalgleish R, Maglott DR, Hart RK, Greenblatt MS, McGowanJordan J, Roux A-F, Smith T, Antonarakis SE, Taschner PEM. HGVS Recommendations for the Description of Sequence Variants: 2016 Update. Hum Mutat. 2016:6:564-9. https://doi.org/10.1002/humu.22981.

16. Solodskikh SA, Panevina AV, Gryaznova MV, Gureev AP, Serzhantova OV, Mikhailov AA, Maslov AY, Popov VN. Targeted sequencing to discover germline variants in the BRCA1 and BRCA2 T genes in a Russian population 
and their association with breast cancer risk. Mutat Res Fund Mol Mech Mutagen. 2019;813:51-7. https://doi.org/10.1016/j.mrfmmm.2018.12.005.

17. Bogdanova NV, Antonenkova NN, Rogov YI, Karstens JH, Hillemanns P, Dork T. High frequency and allele-specific differences of BRCA1 founder mutations in breast cancer and ovarian cancer patients from Belarus. Clin Genet. 2010;78:364-72. https://doi.org/10.1111/j.1399-0004.2010.01473.x.

18. Iyevleva AG, Suspitsin EN, Kroeze K, Gorodnova TV, Sokolenko AP, Buslov KG, Voskresenskiy DA, Togo AV, Kovalenko SP, van der Stoep N, Devilee P, Imyanitov EN. Non-founder BRCA1 mutations in Russian breast cancer patients. Cancer Lett. 2010;298. https://doi.org/10.1016/j.canlet.2010.07.013.

19. Cybulski C, Kluźniak W, Huzarski T, Wokołorczyk D, Rusak AKB, Stempa K, Gronwald J, Szymiczek A, Bagherzadeh M, Jakubowska A, Dębniak T, Lener M, Rudnicka H, Szwiec M, Jarkiewicz-Tretyn J, Stawicka M, Domagała P, Narod SA, Lubinski J. The spectrum of mutations predisposing to familial breast cancer in Poland. Int J Cancer. 2019. https://doi.org/10.1002/ijc.32492.

20. "dbSNP,". Available: https://www.ncbi.nlm.nih.gov/snp/rs80356860.

21. Koczkowska M, Krawczynska N, Stukan M, Kuzniacka A, Brozek I, Sniadecki M, Debniak J, Wydra D, Biernat W, Kozlowski P, Limon J, Wasag B. Spectrum and Prevalence of Pathogenic Variants in Ovarian Cancer Susceptibility Genes in a Group of 333 Patients. Cancers. 2018;10(11):442. https:/doi.org/ 10.3390/cancers 10110442.

22. Kowalik A, Siołek M, Kopczyńsk J, Krawiec K, Kalisz J, Zięba S, Kozak-Klonowska B, Wypiórkiewicz E, Furmańczyk J, Nowak-Ozimek E, Chłopek M, Macek P, Smok-Kalwat J, Góźdź S. BRCA1 founder mutations and beyond in the polish population: a single-institution BRCA1/2 next-generation sequencing study. PLoS One. 2018. https://doi.org/10.1371/journal.pone.0201086.

23. Rudaitis V, Mikliusas V, Januska G, Jukna P, Mickys U, Janavicius R. The incidence of occult ovarian neoplasia and ancer in BRCA1/2 mutation carriers after the bilateral prophylactic salpingo-oophorectomy (PBSO): a single-center prospective study. Eur J Obstet Gynecol Reprod Biol. 2020;247: 25-31. https://doi.org/10.1016/j.ejogrb.2020.01.040.

24. Nasedkina TV, Gromyko OE, Emelyanova MA, Ignatova EO, Kazubskaya TP, Portnoi SM, Zasedatelev AS, Lyubchenko LN. Genotyping of BRCA1, BRCA2, and CHEK2 Germline mutations in Russian breast Cancer patients using diagnostic biochips. Mol Biol. 2014;48:207-2013. https://doi.org/10.1134/ S0026893314020149.

25. Landrum MJ, Lee JM, Benson M, Brown G, Chao C, Chitipiralla S, Gu B, Hart J, Hoffman D, Hoover J, Jang W, Katz K, Ovetsky M, Riley G, Sethi A, Tully R, Villamarin-Salomon R, Rubinstein W, Maglott DR. ClinVar: public archive of interpretations of clinically relevant variants. Nucleic Acids Res. 2016;44(D1): 862-8. https://doi.org/10.1093/nar/gkv1222.

26. Findlay GM, Daza RM, Martin B, Zhang MD, Leith AP, Gasperini M, Janizek $J D$, Huang X, Starita LM, Shendure J. Accurate classification of BRCA1 variants with saturation genome editing. Nature. 2018;562(7726):217-22. https://doi.org/10.1038/s41586-018-0461-z.

27. Diez O, Osorio A, Duran M, Martinez-Ferrandis Jl, de la Hoya M, Salazar R, Vega A, Campos B, Rodriguez-Lopez R, Velasco E, Chaves J, Diaz-Rubio E, Cruz JJ, Torres M, Esteban E, Cervantes A, Alonso C, Roman JMS, Gonzalez-Sarmiento R, Miner C, Carracedo A, Armengod ME, Caldes T, Benitez J, Baiget M. Analysis of BRCA1 and BRCA2 Genes in Spanish Breast/Ovarian Cancer Patients: A High Proportion of Mutations Unique to Spain and Evidence of Founder Effects. Hum Mutat. 2003;22:301-12. https://doi.org/10.1002/humu.10260.

28. Wappenschmidt B, Becker AA, Hauke J, Weber U, Engert S, Kohler J, Kast K, Arnold N, Rhiem K, Hahnen E, Meindl A, Schmutzler RK. Analysis of 30 Putative BRCA1 Splicing Mutations in Hereditary Breast and Ovarian Cancer Families Identifies Exonic Splice Site Mutations That Escape In Silico Prediction. PLoS One. 2012;7(12). https://doi.org/10.1371/journal.pone.0050800.

29. Nelis M, Esko T, Mägi R, Zimprich F, Zimprich A, Toncheva D, Karachanak S, Piskácková T, Balascák I, Peltonen L, Jakkula E, Rehnström K, Lathrop M, Heath S, Galan P, Schreiber S, Meitinger T, Pfeufer A, Wichmann H-E, Melegh B, Polgár N, Toniolo D, Gasparini P, D'Adamo P, Klovins J, Nikitina-Zake L, Kucinskas V, Kasnauskiene J, Lubinski J, Debniak T, Limborska S, Khrunin A, Estivill X, Rabionet R, Marsal S, Julià A, Antonarakis SE, Deutsch S, Borel C, Attar H, Gagnebin M, Macek M, Krawczak M, Remm M, Metspalu A. Genetic Structure of Europeans: A View from the North-East. PLoS One. 2009;4(5): e5472. https://doi.org/10.1371/journal.pone.0005472.

30. "Central Statistical Bureau of Latvia"Available: csb.gov.lv. [Accessed 0212 2020].

\section{Publisher's Note}

Springer Nature remains neutral with regard to jurisdictional claims in published maps and institutional affiliations.

Ready to submit your research? Choose BMC and benefit from:

- fast, convenient online submission

- thorough peer review by experienced researchers in your field

- rapid publication on acceptance

- support for research data, including large and complex data types

- gold Open Access which fosters wider collaboration and increased citations

- maximum visibility for your research: over $100 \mathrm{M}$ website views per year

At BMC, research is always in progress.

Learn more biomedcentral.com/submissions 